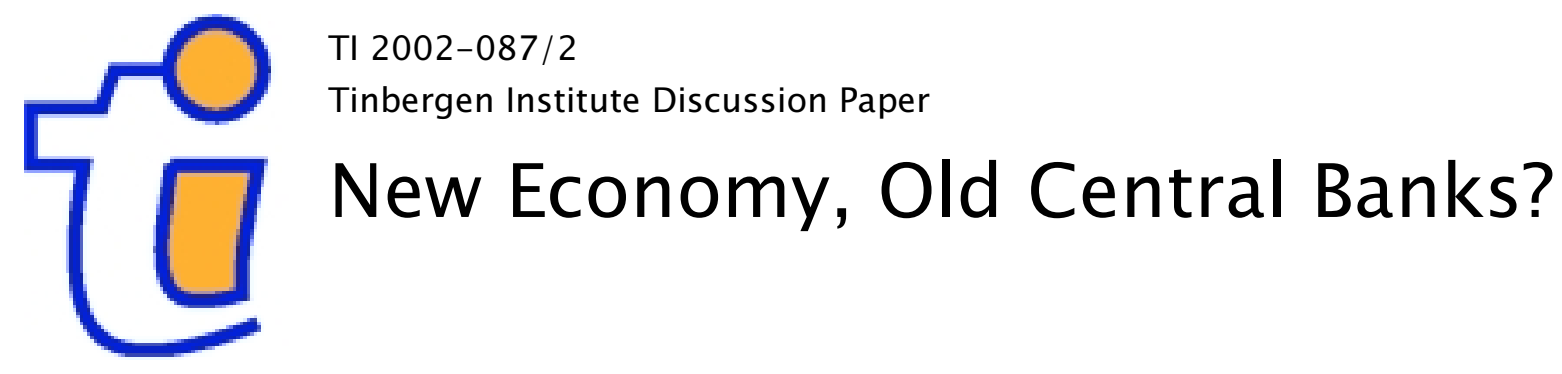

Jan Marc Berk

Monetary and Economic Policy Department, De Nederlandsche Bank, and Faculty of Economics and Business Administration, Vrije Universiteit Amsterdam, and Tinbergen Institute. 
Tinbergen Institute

The Tinbergen Institute is the institute for economic research of the Erasmus Universiteit Rotterdam, Universiteit van Amsterdam and

Vrije Universiteit Amsterdam.

Tinbergen I nstitute Amsterdam

Keizersgracht 482

1017 EG Amsterdam

The Netherlands

Tel.: +31.(0)20.5513500

Fax: $\quad+31 .(0) 20.5513555$

Tinbergen Institute Rotterdam

Burg. Oudlaan 50

3062 PA Rotterdam

The Netherlands

Tel.: $\quad+31 .(0) 10.4088900$

Fax: $\quad+31 .(0) 10.4089031$

Most TI discussion papers can be downloaded at

http://www.tinbergen.nl 


\title{
New Economy, old central banks? \\ Monetary transmission in a new economic environment
}

\author{
Jan Marc Berk*
}

First version: March 2001

This version: August 2002

\begin{abstract}
Summary
Proponents of the so-called New Economy claim that it entails a structural change of the economy. Such a change, in turn, would require the central bank to rethink its monetary policy to the extent that traditional relationships between inflation and economic growth are no longer valid. But such a rethinking presupposes that prospective advances in information technology and other factors associated with the new economy do not threaten the capacity of central banks to stabilise the general level of prices. It is the aim of this paper to shed some light on the latter, by analysing the monetary transmission mechanism in a 'new economy' environment. We argue that, although the form of central bank instruments and current methods for implementing monetary policy may change, the goals that the policy makers try to achieve by employing these instruments remain valid, and achievable.
\end{abstract}

Keywords: Electronic money, New Economy, Monetary policy

JEL codes: E51, E52, E58

\footnotetext{
* Monetary and Economic Policy Department, De Nederlandsche Bank, Faculty of Economics and Business Administration, Vrije Universiteit and Tinbergen Institute Amsterdam. Correspondence: PO Box 98, 1000AB Amsterdam, The Netherlands. Tel: +31 20 5243912. Fax: +31 20 5242506. Email: j.m.berk@dnb.nl. Any views expressed in this paper are the author's solely, and do not necessarily reflect the position of De Nederlandsche Bank or the ESCB. For helpful suggestions, we are grateful to Ron Berndsen, Bryan Chapple, Job Swank, 2 anonymous referees and participants of conferences at the Federal Reserve Bank New York, European Central Bank and participants of the annual meeting of the Western Economic Association, San Francisco. The usual disclaimer applies.
} 


\section{Introduction}

Within the euro area, electronic money currently is relatively intensely used in the Netherlands. The advent of software-based electronic money instruments has spurred research (see, among others, Boeschoten and Hebbink, 1996; Visser, 1996; Groeneveld and Visser, 1997) investigating the monetary policy implications of these technological innovations on the retail side of the payments system. This research points to a gradual substitution of currency by its electronic counterpart (currently mostly multi-purpose prepaid cards). As currency by itself is neither a useful operational or intermediate target nor a relevant channel of transmission of monetary policy, this type of financial innovation is unlikely to inhibit, in any substantial way, the formulation of monetary policy (Henckel et al., 1999). Indeed, recent work by the European Central Bank (ECB, 2000b) seems to take the same position.

However, innovations influencing the wholesale side of the payments system, both in gross and in net clearing systems, suggest the possibility of a less benign outlook for the monetary policy maker (Lahdenperä, 2001). The main reason for this is that these innovations affect the demand for reserves by financial intermediaries, which is at the core of the monetary transmission mechanism in modern economies. This manifestation of the development of e-money may diminish the need for bank reserves at the central bank. It thus has (in the absence of regulatory measures) the potential of eliminating the monopoly position of central banks as suppliers of the means of payment (Woodford, 2000), with negative consequences for the ability of central banks to conduct monetary policy.

The evolution of electronic means of payment is but one of the manifestations of 'New Economy'-type of developments directly impacting on the central bank and monetary policy in particular. Advances in information technology also influence the structure of (financial) markets, the (financial) behaviour of economic agents and the types of (financial) products traded; that is the entire monetary transmission mechanism. For example, advances in data processing and the easier access to information erode the comparative advantage of banks as intermediaries in an environment characterised by information asymmetries. New financial products such as securitised assets are a proliferation of non-bank credit. Households and firms increasingly turn directly to financial markets when making spending decisions. Moreover, the IT revolution enables the creation of new clearing mechanisms which can compete with the central banking settlement systems (King, 1999).

This paper is one of the first attempts to put together all these developments and provide a coherent discussion of the probable effects of the new economy on the monetary transmission mechanism.To this end we first discuss, in the next section, the concept of 'new economy'. A similar conceptual discussion, related to the transmission mechanism, is the subject of section 3 . We disect the transmission process in a number of stages, which are dealt with, respectively, in sections 4 to 6 .

Section 7 concludes. 


\section{New Economy-conceptual issues}

Defining the concept 'New Economy' is a daunting task; in fact, nobody has yet provided a precise definition. Most of the macroeconomic discussions to date seem to relate the new economy to a permanent rise in either the level or the growth rate of potential output, with an increase in the growth rate of trend productivity being the main component of this increase in growth (see, for example, Bullard and Schaling, 2000). The new economy would also seem to be characterised by a reduction in structural and frictional unemployment. What therefore appears to be meant by the new economy is that the speed limits of the economy have been increased, that is the new economy can operate at higher rates of growth than in the past without generating an acceleration in inflation (Jorgenson and Stiroh, 2000). Most of the current literature (see, for example, Oliner and Sichel, 2000, OECD, 2000 and European Union, 2000) then proceeds by examining whether the existence of a new economy can be detected empirically. The latter is not clear-cut, especially in Europe (ECB, 2000a).

The task we set ourselves to achieve in this paper is somewhat different, however. Specifically, we seek to analyse the possible effects of the new economy on the monetary transmission mechanism, a concept which we will define shortly. In doing so, we take as a starting point the existence of a new economy. The description of the new economy as given above is not very useful for our purposes, since we need to relate the new economy to the entire process of monetary transmission, instead of just to the final part in the chain, that is inflation and growth. We therefore proceed by identifying the main variables which theory would suggest are plausible candidates as driving forces of the new economy, see, e.g. Buiter (2000) and Wadhwani (2001). In this respect, most attention has tended to be focused on the effects of an acceleration in the diffusion of the dramatic advances in information and communication technologies, or ICT. Meijers (2000) for example shows analytically how the diffusion of ICT across the economy can account for some of the recently observed empirical phenomena, see also Gordon (2000). However, despite its unquestionable importance, the driving forces of the new economy go beyond just the ICT revolution (Cecchetti, 2000; Wadhwani, 2000 and Baily, 2001). In this respect, the following indicators are also relevant, as they are usually seen as catalysts for the effects on inflation and output which are relevant in a new economy context. They include innovations in the field of the development and use of financial products, including risk management techniques; domestic financial market liberalisation and the globalisation of these markets; the globalisation of trade in goods and services; increasing labour market flexibility; increased product market competition, and improved macro-economic management (ie a credible preference for price stability and reduction of budget deficits).

By focusing on these phenomena, it becomes clear that the new economy is in fact not something new ${ }^{1}$. Some of these factors, such as financial market liberalisation and globalisation,

\footnotetext{
${ }^{1}$ For similar views, see for instance Bartelsman and Hinlopen (2000), Hessius (2000), Plosser (2000). Every time an economy has undergone significant structural changes, it has been regarded as a new economy. As early as in the
} 
already have a fairly long history, see, for example, Bordo, Eichengreen and Kim (1998), and Bordo, Eichengreen and Irwin (1999). We view the new economy as a dynamic process which results from an interaction ${ }^{2}$ of all these factors, the end result of which could be that the speed limits of the economy are raised. We are interested in analysing the consequences of this process for the monetary transmission mechanism. It is to a description of the latter to which we now turn.

\section{$3 \underline{\text { Monetary transmission mechanism }}$}

The monetary transmission mechanism consists of several channels, all of them interlinked and each of them comprising of several stages, see Berk (2001). Central to these different views are alternative conceptions regarding important structural and institutional factors, more specifically the functioning of credit, labour and product markets. As will be discussed in detail below, the above-mentioned factors associated with the new economy will impact on the channels of the monetary transmission mechanism by affecting the functioning of markets. We should note at the outset, however, that no attempt is made to rank (the strength of the) different transmission channels, as our primary focus will be on analysing the impact of the new economy on each channel.

To illustrate the working of the monetary transmission mechanism and the role of these factors it is useful, for presentational purposes, to highlight the following elements. ${ }^{3}$ First, the influence of changes in the instrument variables on the cost of finance. Second, the influence of changes in the cost of finance on expenditure decisions of private-sector agents, i.e. on non-financial activity. The latter is defined to include inflation and real economic activity. Third, the pass-through of changes in non-financial activity to output and inflation. Underlying this division of the transmission mechanism into separate stages is the conception that markets do not necessarily clear instantaneously. If, on the other hand, all markets did always clear, the transmission mechanism would be fairly trivial. A change in the instrument variable would immediately lead to a compensating change in the price level, without

having consequences for output. The classical dichotomy would be maintained. ${ }^{4}$ This is not to say that the new economy could not, by increasing the availability of information and reducing transaction costs,

1960's, Kahn and Wiener (1967) discussed the emergence of a new economy in the context of the spread of ICT. ${ }^{2}$ For example, information technology, financial innovation and globalisation are intimately linked. By reducing the cost of communications, ICT has helped to globalise product and capital markets. In turn, globalisation spurs competition and therefore innovation, and speeds up the diffusion of new technology through trade and investment. Also, flexible labour and product markets tend to go hand in hand with a market-oriented financial system, which in turn is the predominant form of new economy financing, see Houben and Kakes (2001). For further details on the various interactions, see, for example, Buiter (2000) and Sijben (2000).

${ }^{3}$ The transmission mechanism is a dynamic process, in that it represents a sequence of events taking place at successive moments in time. The ordering below reflects the timing of this sequence.

${ }^{4}$ This line of reasoning implicitly follows traditional real business cycle theory (Kydland and Prescott, 1982). However, the assumption of market clearing does not necessarily imply a trivial transmission mechanism. Counterexamples are the stochastic general equilibrium models which incorporate money, for example within the cash-in-advance framework (Cooley and Hansen, 1995). For a critical analysis of the latter framework, see Bengtsson (2000a). Even more interesting from the point of view of the new economy, Woodford (1998) shows analytically that 
be interpreted as a move towards the textbook model of perfect competition (McTeer, 2000). As will be further discussed in section 6 below, it could be argued that, if one were to extrapolate the factors mentioned in the previous section ad infinitum, the result would closely resemble the perfect competition paradigm. However, while conceivable enough from a theoretical point of view, the prospects for this paradigm of coming into reality in the foreseeable future can be put into question. The main part of our analysis will therefore be devoted to an investigation not of the end result of the new economy, but on the process towards it and of the most likely implications for the various transmission channels of monetary policy.

\section{The influence of changes in the instrument variable on the cost of finance}

The presumption underlying this stage is that there exists a mechanism that links the purely financial operations of the central bank to the non-financial decisions made by economic agents. More specifically, it is assumed that the monetary authority exercises power over economic behaviour of private-sector agents by influencing the financial (opportunity) cost relevant to the spending decisions of these agents. The typical operational target used by central banks is the overnight rate, which it broadly determines through its monopoly control, notably by open market operations, of the monetary base, ie the currency outstanding and the deposits held with central banks by commercial banks (Crockett, 1994; Mishkin, 1996). According to BIS (1994), the pass-through from these overnight rates to short-term market interest rates is fairly complete in most industrialised countries. The central bank therefore is able to control the short-term market interest rate. Although this position is currently relatively unchallenged (see also Bernanke and Blinder, 1992; Mauskopf, 1990), the question arises how the new economy impacts on this central bank control of the overnight rate. Put differently, what are the consequences of the new economy for the influence the central bank currently has on the monetary base. Moreover, if that influence would disappear, is the central bank still able to control short-term interest rates? We will discuss these issues in turn.

\section{Central bank influence on the monetary base}

The most visible advance in ICT with a possible impact on (the relevance of) central bank influence on the monetary base pertains to the development of convenient ways of executing payments electronically that might in the past have required the use of central bank issued currency. These electronic innovations often have been loosely labelled by the term electronic money, or e-money. Although the medium-ofexchange function probably is the most important in a discussion of electronic currency substitutes (Ely, 1997; England, 1997; Berentsen, 1998; ECB, 2000b), it is important for what follows to note that money performs more roles than facilitating transactions. Indeed, defining the concept of money is by no means an easy task (see Dalziel, 2000, for a comprehensive survey and Bengtsson, 2000a, 2000b for a theoretical analysis), and the same holds for its electronic variant. Standard economic textbooks attribute 
to it three characteristic functions: medium of exchange, a store of value and unit of account. The legal definition of electronic money as currently prevailing in Europe for instance reflects most of these functions. ${ }^{5}$

It is convenient for what follows to distinguish between three classes of electronic means of payment, ie e-transfers, e-purses and e-money proper (White, 1997; Lelieveldt et al., 2000). E-transfers are defined as transfers which are not based on paper as a source document (an example of the latter would be checks). A subset of e-transfers is e-purses, the most prominent example of which are multipurpose stored value cards or smart cards which figure prominently in European countries and Japan. ${ }^{6}$ Value transferred from payer to payee via e-purses can not, in general, be used again, but has to be forwarded to the issuer for redemption. E-purses that allow for the direct transfer of credit balances from purse to purse, without the immediate involvement of the issuing (financial) institution, fall into the category of e-money proper.

While all of these concepts initiate an electronic transfer of value between two transaction accounts, only balances of e-money proper are circulating bearer media. When issued by private parties, they can be considered to fullfill a full-fledged medium of exchange role which has the potential to evolve to a substitute for central bank currency. ${ }^{7}$ A balance of e-money proper represents a floating claim on the issuer that is not linked to any particular account (White, 1997). To the extent that the issuer is not a central bank, there will be a transfer of seigniorage from the central bank to the private (financial) institution issuing e-money (Groeneveld and Visser, 1997; Berentsen, 1998). ${ }^{8}$ If e-money proper becomes so entrenched in the preferences of economic agents (for example, when it completely dominates alternatives in terms of convenience and low cost; Rahn, 2000), it could replace not only central bank currency but also traditional bank demand deposits and other types of highly liquid deposits. ${ }^{9}$ If this leads to a situation in which the claims that people exchange in order to execute transactions are no longer claims on the books of banks (or are no longer backed one for one by bank deposits), problems for the efficacy of monetary policy could arise as the connection between the change in reservable bank deposits and the change in non-financial activity will be weakened (Gilbert, 1997).

\footnotetext{
${ }^{5}$ According to article I of the European Parliament and Council Directive 2000/46/EC, 'electronic money shall mean monetary value as represented by a claim on the issuer which is (i) stored on an electronic device; (ii) issued on receipt of funds of an amount not less in value than the monetary value issued, (iii) accepted as means of payment by undertakings other than the user'.

${ }^{6}$ Examples of e-transfers not belonging to e-purses include access products, such as debit cards, credit cards, ATM's, and home banking, in which payments are settled by way of transfers between bank accounts, and payment instruments as pre-paid telephone cards, which are accepted as payment only by their issuer.

${ }^{7}$ In addition, if ICT were to significantly reduce the demand for currency by the general public, the depository institutions' derived demand for vault cash would also diminish. For an analysis of vault cash, see Bennett and Peristiani (2001).

${ }^{8}$ Today, almost all proposed e-money schemes are developed by private institutions. The issuer, however, could also be a central bank.

${ }^{9}$ E-money is characterised by relatively high fixed costs, due to the need to rely on new technologies, but low marginal costs, as the cost of processing a single transaction is very small. This makes e-money especially suitable for making frequent and small payments. Moreover, it is likely that there will be a network effect. That is, once a critical mass is reached, a new payment instrument develops more quickly because its usefulness is an increasing function of the number of individuals who use it in executing transactions. Finally, the likelihood of e-money becoming a substitute
} 
There are, however, (regulatory or institutional) ways to get around this problem. Examples include extending the reserve requirements to all entities in the business of issuing these claims or requiring tax payments to be made using claims backed by bank deposits (Jordan and Stevens, 1997; Goodhart, 2000). The regulatory path seems to be favoured in Europe, see ECB (2000b), whereas the US seems to follow a more liberal attitude in this respect (Greenspan, 1997).

However, the development of e-money proper is as yet mainly a theoretical concept ${ }^{10}$ and not a practical reality (BIS, 1996a). Moreover, it is unlikely that ICT will have the potential to completely eliminate the demand for central bank issued currency, owing, among other things, to the uniquely convenient features as a means of payment ${ }^{11}$ of central bank currency as well as its status of being legal tender (Goodhart, 2000). But even a significant reduction in the demand for central bank issued currency might not necessarily pose a problem for the central bank. First, it is well known that it is not the size of the central bank balance sheet that matters in this respect, see Tobin and Brainard (1963). What matters is that changes in the size of the central bank balance sheet, or the interest rate the central bank can set, are at the margin related to changes in the volume and price of assets and liabilities that the public needs to engage in economic activity (Friedman, 2000a). Since central bank issued currency by convention (but not by necessity, see Goodhart, 1993) earns no interest, the issue thus is how closely the expansion or contraction of the remaining activities requiring central bank currency matches the expansion or contraction of the overall economy that the central bank seeks to influence. ${ }^{12}$ Second, central banks usually passively accomodate currency demand, in stead of trying to fix its supply (Ely, 1997; Freedman, 2000). That is, as central bank issued currency is probably not very relevant in monetary policy implementation, its demise, if this ever happens, is also unlikely to be important (Woodford, 2001).

Currency is but one of the components of base money. We therefore now turn to a discussion of the effect of the new economy on the demand for central bank deposits by depository institutions. These institutions hold an account balance with the central bank mainly to satisfy reserve requirements and for use as settlement balances. Consider first reserve requirements. The introduction of the so-called sweep accounts in the US illustrates the relevance of the new economy, via the introduction of faster information processing, for central banks. It gives an impetus to innovations that facilitate the transfer of funds by depository institutions between their accounts not subject to reserve requirements and the

\footnotetext{
for bank deposits would increase were e-money to be remunerated.

${ }^{10}$ The proliferation of various privately issued e-monies implies multiple media of exchange, stores of value, and, in principle, units of account (on the latter, see however Bengtsson, 2000a). Regulation can preserve the current uniqueness of the unit of account function performed by central bank issued money, for example by imposing a redeemability requirement on issuers of e-money (ECB, 2000b). For a theoretical rationale, see Issing (1999). The cost structure of e-money, characterised by high fixed and low marginal cost, however deters such a proliferation. In fact, as indicated by Shapiro and Varian (1999), it introduces a tendency towards a natural monopoly ('winner takes all'). ${ }^{11}$ Currency is, for example, completely anonymous, and is less prone to loss, theft and counterfeiting than electronic transfers (Ely, 1997; Kabelac, 1999). It moreover provides finality in settlement.

${ }^{12}$ Note that, since central bank-issued currency earns no interest, it is at a competitive disadvantage to private issuers of emoney who do offer remuneration for holding e-money balances. This of course touches on the free banking issue, see, for example, Black (1970); Hayek $(1976,1978)$; White $(1984,1989)$. Goodhart $(1986,1989)$ and Issing (1999) provide a
} 
balances that are, thereby allowing payments to be made while maintaining low average balances subject to the reserve requirements (White, 2000). This type of behaviour can of course be countered by new regulation. However, the long-term success of the regulator in the ensuing regulatory rat race can be called into question when the regulations are not sufficiently market-oriented (Browne and Cronin, 1997). For statutory reserve requirements that compel a depository institution to hold reserves it can not use or that pay subcompetitive interest rates act as an implicit tax, which innovators will always have an incentive to circumvent. The notion that regulators can permanently swim against the tide of innovation is criticised by Friedman (1999). ${ }^{13}$ The worldwide trend towards the elimination of reserve requirements is also indicative in this respect. ${ }^{14}$

In addition to satisfying regulatory requirements, depository institutions also hold reserves at the central bank in order to pay one another. That is, reserves function as a means of settling interbank transactions through the central bank's clearing mechanism. This demand for central-bank settlement balances is mainly precautionary. Without uncertainty about payment transactions, a depository institution could plan perfectly ahead and always have the exact amount of reserves necessary. However, with uncertainty, a depository institution needs to minimise the risk of incurring a penalty over the market rate when unable to meet settlement obligations by the end of the day. This generally results in a positive demand for intraday reserves (Poole, 1968; Baltensperger, 1974; Woodford, 2001). By reducing this uncertainty, advances in information technology usually associated with new economy impact on the demand for settlement balances. More specifically, payments system innovations, both in gross and net clearing systems, have increased the efficiency and safety with which banks clear and settle interbank transactions, thereby potentially reducing the demand for intraday reserves (Henckel et al., 1999). ${ }^{15}$ Moreover, another important factor related to the new economy, financial market liberalisation and deregulation, increases the liquidity of securities (BIS, 1998) providing depository institutions with an important substitute for central bank reserves. Instead of holding settlement balances, banks hold liquid securities which they can use at any time to borrow the settlement balances that they exactly need to avoid end-of-day overdrafts in their current account at the central bank.

Although these new economy factors work towards a reduction of the demand for settlement balances, it is likely that some residual demand will continue to exist, due to, for example, strategic bank

\footnotetext{
critical analysis.

${ }^{13}$ Gilbert (1997) however seems to reach a different conclusion.

${ }^{14}$ In most of the countries still using them, the requirements no longer function as an instrument for monetary control.Their residual role in stead is their use as liquidity buffer. Note that in countries which completely abolished requirements, monetary policy still remains effective (although operating procedures for policy implementation have changed). See Sellon and Weiner (1996, 1997), and Woodford (2000).

${ }^{15}$ Gross settlement systems have the advantage of ensuring finality, whereas netting systems limit the need for settlement balances, for which a 'price' is paid in terms of settlement risk. Observance of the Lamfalussy standards (BIS, 1990), however, has considerably reduced this risk. On the other hand, sophisticated queueing algorithms, the provision of collateralised intraday liquidity by central banks and an efficient interbank market for central bank money have reduced the need for intraday liquidity in gross settlement systems. Thus, differences between gross and net systems tend to diminish over time.
} 
behaviour or other market imperfections. ${ }^{16}$ Debtor banks may, for example, be unable to locate a potential lender in time or lenders may not offer loans at suitable conditions for strategic reasons. When the marginal creditor bank in the market must negotiate a price at which to lend resources to the marginal debtor bank, a game situation arises in which the creditor bank may be tempted to 'corner' the debtor bank (ie adopt non-cooperative behaviour). These arguments point to a reduced, but nonetheless positive, demand for settlement balances, which are currently almost exclusively provided by the central bank. ${ }^{17}$ As in note issue, central banks have taken on this role largely because private providers have been legally restricted or nationalised (White, 2000). From an economic point of view, the main comparative advantage that central banks currently hold over (potential) private competitors pertains to the fact that they provide settlement finality as a payment service (Issing, 2000). That is, final settlement represents an ultimate, official guarantee of values exchanged by depository institutions and their customers (Jordan and Stevens, 1997). ${ }^{18}$ However, there are no intrinsic reasons why final

settlements could not be carried out by the private sector without the need for clearing through the central bank. ${ }^{19}$ The practical implementation of such a system (a description of which is provided by,for example, Browne and Fell, 1994 and Browne and Cronin, 1997) would possibly require computers that communicate in real time to permit the instantaneous verification of the creditworthiness of counterparties, which presumably is beyond the computer power that is currently available (King, 1999). Moreover, the real-time transfer of wealth between electronic accounts needed to settle a transaction of goods or services would probably involve financial assets. Eligible assets would include any financial assets for which there are market-clearing prices in real time. This also requires formidable computing power (in addition to well-functioning and liberalised financial markets). However, the factors identified in section 2 work into the direction of making all this available to more private parties at progressively lower cost. So, new economy induced competition can erode the central bank monopoly in the market for settlement balances.

\section{Central bank control of short-term rates with substitutes for base money}

The new economy thus could, in the limit, lead to a situation in which the demand for settlement balances is severely reduced, and the position of the central bank in the market for settlement balances is

\footnotetext{
${ }^{16}$ It can be seen from economic history that, even before the nationalisation of clearing and the advent of reserve requirements, banks held positive reserves (White, 1989).

${ }^{17}$ This central bank monopoly is complete in Europe, whereas in the US private clearing mechanisms exist, such as the CHIPS system of the New York Clearing House Association.

${ }^{18}$ Note the rather paradoxical fact that the advent of privately issued electronic purses (which threaten central bank issued currency) for the time being strenghtens the central bank position in the market for settlement balances, as final net settlement of imbalances between these monies will be in the form of central bank liabilities.

${ }^{19}$ Freedman (2000), however, doubts whether the special role of central banks in providing settlement balances could ever be replaced, even in the absence of legal requirements for depository institutions to settle with the central bank. His argument hinges on a priviliged relation between the central bank and the government. Whether this has
} 
next to completely marginalised. In combination with a diminished demand for central bank currency, this could lead to a situation in which central bank liabilities approach zero. Woodford (1998) has shown that in this 'cashless limit' (ie a situation in which there is some, possibly infinite small, demand for central bank reserves), the price level is still determined, and the central bank is still able to influence overnight interest rates by changing its operational target. What is different, however, is that in such a world the use of quantity-targeting techniques (ie rationing bank reserves) to control interest rates (such as currently applied in the US) may become ineffective, especially when the residual demand becomes highly inelastic or unstable. It may have to be replaced by a more price-oriented system, see also Friedman (2000a). Under such a system the central bank operates a borrowing facility at which an arbitrary quantity of reserves may be borrowed (subject to suitable collateral) at an announced rate. Variations in this rate then is the tool by which desired variations in the operational target are achieved.

Beyond this limit lies a true 'moneyless' world ${ }^{20}$ in which e-money proper perfectly substitutes central bank issued currency, in which final settlement could be made without recourse to the central bank, and in which there are no cost advantages for depository institutions to using central-bank settlement balances. Even in this economy, sometimes labelled as 'fully frictionless' (Woodford, 2000; McCallum, 2000; Bengtsson, 2000b), the central bank still has the ability to influence the level of the overnight rate, as long as it is willing to change the interest rate that it pays on reserves. ${ }^{21}$ Although currently base money is not remunerated in the US, the remuneration of settlement balances is certainly not without precedent. In fact, a number of countries currently pay interest on balances that depository institutions hold at the central bank, eg. Canada, New Zealand, Australia. Indeed, some of these countries already control short-term interest rates by varying the interest rate paid on balances held with the central bank, rather than by injecting or absorbing liquidity in such an amount as to induce a desired differential between that interest rate and the overnight rate. In a world in which there exist (perfect) substitutes for bank reserves, only a zero differential is compatible with a positive demand for base money, and conducting a monetary tightening by trying to increase the spread would result in a complete substitution away from reserves towards the higher-yielding privately issued liquid assets (Woodford, 2000, 2001). Instead, the central bank can steer short-term market rates in a direction it desires by bringing about changes in the interest rate paid on base money; more specifically, it should adjust the interest rate on marginal central bank balances with changes in the target level of overnight rates. That is, for a tightening the central bank raises the nominal return on base money, which by virtue of arbitrage and the perfect substitutability characteristic also raises the nominal return on non-monetary assets to an extent that is consistent with price stability (Woodford, 2000; Hall, 1999). As the choice of the nominal rate of

\footnotetext{
consequences for central bank independence is an interesting topic for subsequent research.

${ }^{20}$ In 'conventional' monetary exchange systems the basis medium of exchange (commodity money or fiat money) invariably has served as the unit of account. In a moneyless world, there is no longer a tangible medium of exchange, and so the choice (and even the number) of the unit of account becomes less obvious, see Fama (1980, 1983).

${ }^{21}$ In such an economy, the demand for base money would, in the absence of remuneration of reserves, equal zero (Woodford, 2000).Clearly, in the absence of demand, varying the supply (either by announcing a quantity or a willingness to supply at a certain interest rate) will be ineffective in influencing the overnight rate.
} 
interest on central bank liabilities is an arbitrary choice of the central bank, this instrument is always available. The only requirement is that the liabilities of the central bank are always accepted, and that the central bank has access to potentially large amounts of treasury securities. Goodhart (2000) however makes the qualification that the changes in the rates paid on base money must be brought about by selling or buying existing central bank assets, which will imply a reduction of central bank profits (or an increase in losses). Effectively, central banks tighten by the selling of assets out of their portfolio at a lower price (higher return) than their competitors, and loosen by buying assets in exchange for base money at a higher asset price. He does not find this a major problem, because of the non-profitmaximising behaviour of the central bank as a public institution (see also Goodhart, 1985, 1988). However, this could have consequences for the (financial) independence of the central bank, see also Costa and de Grauwe (2001).

So, even in an economy in which 'high-powered money' has lost its power, the central bank will be able to steer the overnight rate. There remains however the question of the role to be played by central banks in such a world described by, for example, Black (1970), as the traditional functions of money will be performed by an infinite number of alternative instruments, which can all be expressed in terms of each other (Fama, 1980; Goodhart, 1989). In that world, monetary policy, that is the maintenance of a constant purchasing power of the unit of account, has no meaning because there will be a number of units of account (Issing, 2000). However, if society were to express a preference for a particular unit of account, in which all alternative instruments would be priced, then it would still be possible for the central bank to regulate the value of this unit of account, as was discussed above. ${ }^{22}$ Note that in such a world the need to limit excessive money creation is replaced by a concern to ensure the integrity of the computer systems used for settlement. Central banks could be seen as a natural candidate for such a supervisory activity.

It is very unlikely that this utopian world will ever become reality. In any case, such a world would probably be preceded by an economy where central banks face a reduced demand for settlement balances and competitors challenge the position of the central bank in this market. It follows from the discussion above that in this situation, a central bank can continue to influence the cost of finance. It can do so by changing its instrument variable, either by choice of economic agents (by offering to lend/borrow unlimited amounts of its liabilities at a (risk adjusted) price which is by definition the most attractive) or by regulation. The latter could be realised by requiring taxes to be paid in central bank liabilities (Friedman, 2000a,b). An alternative would be to ensure that the central bank remains the only entity which is allowed to corner the market for settlement balances by forcing participants to lend or borrow from its facilities at the rates it chooses to impose on the market. For a description of such a system, see Henckel et al. (1999). By being the uncontested broker in the case of settlement difficulties, a

\footnotetext{
${ }^{22}$ Such a preference is likely, since an unique numeraire is an efficient solution to the co-ordination problems involved in negotiating contracts and performing economic calculations, see White (1984) and Issing (1999).
} 
central bank acquires an unique disciplinating capacity which bolsters the credibility of its interest rate announcements and ensures that no private broker takes its place.

\section{The functioning of credit markets and the new economy}

The level of short-term market interest rates affects only a proportion of the financing of expenditure of households and firms. The private sector also finances part of its spending at longer-term rates on the capital market as well as through financial intermediaries (and through other means like retentions and equity issues). The cost of borrowing from these sources is only indirectly influenced by the current level of money market rates. Important determinants of the impact of changes in the instrument variable (the overnight rate) on the cost of finance thus include the substitutability between different forms of finance, the pass-through of changes in market interest rates to bank lending and deposit rates and the impact of changes in short-term interest rates on long-term interest rates. These determinants will likely be affected by the factors associated with the new economy.

The substitutability between different forms of finance and the responses to market rates of lending charges applied by financial institutions is to an important extent dependent on the functioning of credit markets. The new economy is believed to bring closer a neo-classical financial environment without frictions and asymmetric information, that is, a world in which the Modigliani-Miller (1958) theorem holds. In this world, agents in the private sector can, at market interest rates, borrow and lend whatever amounts are necessary to achieve their desired spending patterns. The absence of information imperfections between suppliers and users of funds implies that the substitutability between internal and external financing sources and between different forms of external finance, such as intermediated and non-intermediated credit, is perfect (BIS, 1994). If bank assets and liabilities have identical characteristics to other borrowing and saving instruments, such as bonds, then bank and non-bank instruments will trade at the same price (assuming risk neutrality). The pass-through from market interest rates to bank rates is immediate and complete (Dale and Haldane, 1993). Financial prices in this perfect capital market allocate financial quantities optimally. Interactions between financial variables and nonfinancial activity can be reduced and simplified to interactions between interest rates and non-financial activity. ${ }^{23}$ The main implication would therefore be that, to the extent that information asymmetries and the crucial role of financial intermediaries will be diminished by the new economy, there will be an enhanced role for direct finance with a larger role of private debt securities and equity markets. ${ }^{24}$ In such an environment, interest rate changes may impact on the corporate sector more quickly as financial market prices tend to react more quickly to changes in official rates than retail deposit and lending rates. Thus, monetary policy actions may almost instantaneously affect corporate bond yields and equity

\footnotetext{
${ }^{23}$ As emphasized by Meltzer (1995, 2001), this equilibrium determines not a single interest rate, but a vector of rates, representing the yields on bonds, equity and other assets.

${ }^{24}$ Allen and Santomero (2001) argue that financial intermediaries maintain their crucial role in the financial system despite the reduction in information asymmetries, by swiching from their traditional business to free-producing activities based on risk managemant skills using derivatives.
} 
prices, affecting the cost of direct borrowing, while the impact of official rates on lending rates is currently less immediate. Also, the more competitive financial markets, the greater the inclination of financial intermediaries to adjust their interest rate spreads more promptly and significantly in response to changes in official rates (Mojon, 2000).

\section{Non-price component of cost of finance}

However, since the seminal paper by Akerlof (1970) it is well-known that the efficient functioning of the market for credit is hindered by asymmetries in information between borrowers and lenders, resulting in principal-agent problems (Oliner and Rudebusch, 1996). These problems lead to endogenous and varying credit conditions which help to shape the transmission of monetary policy decisions through the economy, see Stiglitz and Weiss (1981), Bernanke (1983), Bernanke and Blinder

(1988). As recognised by, inter alia, Kashyap, Stein and Wilcox (1993), Kashyap and Stein (1994) and Hubbard (1994) this uncertainty generates a potential important role for financial intermediaries which specialise in gathering and distilling agent-specific information. The implication is that financial intermediairies, usually banks, play a unique role in the monetary transmission process, acting as an interface between the policy decisions of the central bank and non-financial activity. Decisions of financial institutions regarding the size of their balance sheets and the yields paid on their assets and liabilities play an active role in the transmission of monetary policies. Because financial institutions obtain a portion of their funds from instruments subject to reserve requirements, open market operations, which alter the quantity of reserves, may affect the opportunity cost of funds to those institutions beyond their impact on market interest rates. That is, financial quantities (the availability of credit) play an important role in this credit view of the transmission mechanism. ${ }^{25}$

The new economy, and the revolution in ICT in particular, increases the amount of information which is available to a greater number of economic agents at an increasingly lower cost. If the increased availability of information reduces the prevalence of information asymmetries, it also implies a reduced role of depository intermediaries in advancing credit to the non-financial economy, as their traditional comparative advantage, information intermediation, erodes, see Allen and Santomero (1998). This disintermediation will result in a further proliferation of nonbank credit (Friedman, 1999). However, the extent to which the importance of the credit view of monetary transmission will be eroded by the new economy remains an open question. As a general remark, increased availability of information does not necessarily imply increased access to information. ${ }^{26}$ And the theoretical basis for the credit channel, the theory of asymmetric information (Akerlof, 1970), stresses that these asymmetries arise because there exist economic agents who benefit from not disclosing their information to others (and that other agents

\footnotetext{
${ }^{25}$ Note that, in addition to the effects described in a previous section, a declining importance of reserve requirements and open market operations will also impact on the transmission mechanism by weakening the credit channel.

${ }^{26}$ In a recent paper, D'Avolio, Gildor and Shleifer (2001) argue (and present evidence to support the claim) that, with the advent of new technologies for disseminating information, there exist strong incentives for economic agents to reduce the quality of the information made public.
} 
know this). It is not likely that this behaviour will change with new ICT (Browne and Cronin, 1997). However, even with a significant part of agents in the economy remaining 'bank dependent' because of continuing information asymmetries, the new economy could have an impact on the role played by financial intermediaries in the transmission mechanism. ${ }^{27}$ To see this, note that innovations on financial markets have now advanced to the point where the bank that investigates the borrower's creditworthiness, originates the loan and services the credit relationship, no longer needs to hold the loan in its own portfolio. Instead, bank loans are often sold to (nonfinancial) firms that package them into aggregated portfolios of similar credits, which in turn stand as collateral behind securities owned and traded by market investors, as well as households who buy these securities directly on their own account. New financial products such as derivatives are used by these agents (either directly or indirectly, via financial intermediaries) to manage the risks incurred by these investments. Securitisation weakens the influence of central banks on the transmission process to the extent that it severs the bank-oriented component of the credit expansion from any direct relation to the central bank's system of required reserves, see Thornton (1994), Mishkin (1996), Friedman (1999) and Estrella (2001). The transformation of non-marketed bank loans into marketable securities thus reduces the role of the credit view even when bank dependency continues, see Chami et al. (1999) and Fender (2000a, b). ${ }^{28}$ Edwards and Mishkin (1995) provide some empirical evidence of this weakening.

\section{Term structure}

The responses of longer-term interest rates to movements in short-term rates are easiest explained under the paradigm of perfect capital markets, as discussed above. If all financial assets (monetary or nonmonetary) are perfect substitutes, there exists only one relative asset price, 'the' interest rate. The difference between the short-term interest rate and the long-term interest rate, or, more generally, changes in market interest rates along the maturity spectrum, will reflect fully the current level and expected future path of short-term interest rates. This is the so-called expectations theory of the term structure (Modigliani and Shiller, 1973), a theory that currently receives little empirical support (Berk, 2001). This should not come as a surprise, as capital markets are not perfect, financial market participants are not risk-neutral and consequently the differences between interest rates of different maturity will not only reflect expectations of future changes in short-term rates, but also risk premia. But

\footnotetext{
${ }^{27}$ Some also argue that the dominant mode of financial intermediation will change due to new economy-related developments (disintermediation and securitisation in particular). The traditional 'par-value' banking system, in which both the deposits and loans are redeemable at par, will in this view be replaced by a 'mutual fund banking'system. In the latter all assets and liabilities are traded on secondary markets and thereby carry varying values (Fama,1980, 1983; Goodhart, 1988; Browne and Fell, 1994). For a critical review, see Goodhart (1986, 1993) and Bossone (2001).

${ }^{28}$ There seem however to be limits to the extent of securitisation, to the extent that certain assets, notably those which do not have a sufficient amount or quality of collateral, remain uncertain. This uncertainty in turn is a cause of the preference for convertability into 'safe' base money. Proponents of the narrow banking movement (Fama, 1980) try to remedy this uncertainty, see Goodhart $(1989,1993)$ for details. Note that the advent of corporate risk management strategies, making use of new financial products such as derivatives, tend to reduce the limits that are traditionally placed on the process of securitisation. See Goodhart (1989, p. 120-121). For a further, and interesting, generalisation of implications of risk sharing, see Shiller (1993).
} 
to the extent that the factors usually identified with a new economy (section 2 above) work in the direction of a move towards perfect capital markets, and the pervasive possibilities for insuring and sharing risk using new financial instruments diminish the importance of risk premia (Shiller, 1993), the expectations theory of the yield curve should fare better in a new economy. The latter should not taken to imply that risk premia will disappear completely and immediately. However, the new economy will tend to reduce and in the limit eliminate imperfections such as transaction costs, brokerage margins between borrowing and lending rates, restrictions on short sales, differential tax considerations, etc. In addition, the use of securitised claims for payments might also ease credit risks, as those claims would be marked-to-market on an ongoing basis and would be transferable in real time. The ensuing increase in portfolio diversification possibilities reduces price discrepancies between assets. Finally, it can not be excluded that the advent of derivatives in the management of risk by economic agents will change their attitude towards risk, perhaps more into the direction of risk neutrality, see Capel and Jansen (2001). This all points towards an increased substitutability of assets across the maturity spectrum (Vrolijk, 1997). The result would be a faster transmission of monetary policy signals along the yield curve.Moreover, by the leverage inherent in the use of derivatives this transmission would also be stronger.

\section{The influence of changes in the cost of finance on non-financial activity}

The impact of changes in the cost of finance (which includes quantity as well as price-related variables) on non-financial activity depends on various factors (Bank of England, 1990). First, changes in the cost of finance induce a substitution between saving and borrowing, as economic agents intertemporally smooth expenditure. Moreover, investment decisions are re-asessed in the light of changed costs of capital, as the latter affect the opportunity cost of real expenditure decisions. This substitution effect mainly influences new borrowing decisions. The direction of this effect is always negative, ie a rise in the cost of finance decreases non-financial activity, and the extent of the impact will depend on the ability of agents to substitute intertemporally. Deregulation and globalisation of financial markets, improvements in ICT as well as advances in risk management techniques and related instruments (derivatives), increasingly enable risks to be traded on financial markets and provide insurance. The new economy therefore improves the intertemporal substitution of income streams (Shiller, 1993). This should work against the substitution effect of monetary transmission. It is, for example, possible to hedge against the adverse impact of the substitution effect: by using structured derivatives such as options on futures, a hedger can lock in the current interest rate for potential future funding needs. The new economy thereby pushes economies towards a more classical-looking world, in which expenditure decisions are determined to a larger extent by expected wealth and relative prices. In this frictionless world it is the real interest rate that matters, because economic agents will typically base their decisions 
on a comparison between what they consume today and what they hope to consume in the future. ${ }^{29}$ Moreover, current income (ie the fraction of wealth which is generated in the current period) should become less important a determinant of current consumption. Net worth would gradually replace cash flow as the primary influence on investment expenditures. There is some empirical evidence to support this position (see Browne and Fell, 1994, for an overview), but it is still far from conclusive whether the substitution effect of monetary transmisson will become weaker. This is mainly because there will remain uncertainties which are not hedgeable. Moreover, hedging comes at a cost (through the option premium for example), which may prove to be prohibitive for some (especially small) economic agents.

Second, changes in the cost of finance lead to changes in average rates on outstanding contracts, modifying incomes and cash flows and hence constraints on spending. This income effect mainly impacts on outstanding borrowing. Its main influence is on agents' liquidity, and its direction depends on the net holdings of assets and liabilities. A net saver receives a positive income effect following an increase in the cost of finance, whereas a net borrower has a negative income effect. The rise thus redistributes income from borrowers to lenders. In practice, the standard life-cycle pattern of employment followed by retirement will lead those obtaining income from labour to be, on balance, net savers. In contrast, the productive investing sector is by nature a net borrower, since it has to issue financial liabilities on itself to purchase the real assets which will subsequently provide the returns to meet the debt obligations. If borrowers have a higher marginal propensity to consume than lenders, then the aggregate income effect is negative. As discussed above, the new economy provides increased insurance possibilities. This is particularly relevant for the income effect of monetary transmission, as derivatives significantly increase the ability of economic agents to hedge the income effect associated with fluctuations in the cost of finance. Hedged agents are either more sensitive to the cost of finance, or more risk averse than agents who end up holding risk. Hedgers could be willing to carry the cost of hedging because they have a higher marginal propensity to consume, and therefore wish to maintain their high consumption (Vrolijk, 1997). Derivatives allow these agents to hedge their exposure to payments and receipts which are sensitive to the cost of finance. It can be argued that the size of the income effect will be reduced due to new-economy induced increased insurance possibilities. Consider that for the duration of the hedge, the complete income effect has been shifted from the hedged agents to the risk holding agents. The hedged agents are not prone to an income effect, whereas the risk holders receive a double income effect. But since it is likely that the risk holders' propensity to consume is lower than that of the hedgers, the income effect is not as negative as if the hedgers had not been hedged. This line of reasoning demonstrates that, for every hedged unit, a risk holder must have acquired the risk, that is, hedging is (in a closed economy) a macroeconomic zero-sum game. ${ }^{30}$ There

\footnotetext{
${ }^{29}$ If the new economy increases profitable investment opportunities, then the real interest rate must increase in order to encourage households to save more to finance the higher level of investment.

${ }^{30}$ However, to the extent that the new economy influences risk trading in such a way that risk ends up with economic agents and institutions most willing and able to bear risk, it improves efficiency. On the other hand, it also has the potential to shift the non-diversifiable risk in the economy to the imprudent (Buiter, 2000).
} 
are thus always some economic agents which are confronted with an income effect. The actual change in the income effect element of the transmission mechanism lies in the difference between the marginal propensities to consume of the hedger and the risk holder. ${ }^{31}$ Moreover, and this also applies to the preceding analysis of the substitution effect, the new economy related factors also work in the direction of a faster transmission of monetary policy to asset prices (as their substitutability increases). This implies that (hedged as well as unhedged) economic agents are impacted by a substitution and income effect sooner. That is, both effects may impact earlier, but are smaller in magnitude.

Third, changes in the cost of finance affect the value of certain assets, such as housing, equities or government bonds. These values, in turn, have an impact on wealth perceptions, which influence spending (Bank of England, 1999). Moreover, this so-called wealth effect influences the ability to borrow and the willingness to lend. As wealth is equal to discounted future net income, its effect in the chain of monetary transmission in principle is closely related to the income effect. There are two ways through which wealth can vary: through changes in income flows and through changes in the discount factor. As the former effect is discussed above, we will focus here on a change in net worth due to a change in prices, see also Mishkin (1996). A reduction in prices of, for example, bonds, equity and real estate, causes a decline in wealth, which, according to the life cycle consumption model (Modigliani, 1971), induces a reduction in non-financial activity. Again, hedging techniques similar to those used for hedging an adverse income effect, tend to reduce the size of the wealth effect. However, since hedging in order to maintain market value of assets currently is less common than using derivatives for earnings or cash flow management (Bodnar and Marston, 1996), its size is probably small relative to hedging against adverse income effects. This is in particular the case for changes in the price of real estate, for which the hedging possibilities are fairly limited, due to the relatively illiquid character of the market for real estate. Finally, to the extent that households and firms are likely to increase the share of securitised financial assets in their portfolios, the wealth effect may gain in importance.

A final factor through which changes in monetary policy instruments influence non-financial activity operates through the exchange rate (Menon, 1995). Under flexible exchange rates, a higher cost of finance due to an interest rate increase attracts foreign capital, thereby appreciating the exchange rate. The higher exchange rate makes domestic goods relatively more expensive than foreign goods, decreasing net exports and (domestic) non-financial activity. Derivatives have the potential to significantly reduce the impact of this transmission channel, to the extent that both wholesale importers and exporters use currency derivatives to hedge nominal exchange rate fluctuations in the short run. Indeed, currency derivatives figure prominently in surveys of derivatives markets (Bodnar and Marston, 1996; BIS, 1996b). However, changes in the cost of finance also induce changes in the real exchange rate, and these are more difficult to hedge, especially when the driving force behind the fluctuations are changes in the relative price level. In this case there is a substitution effect which is not insurable; agents

\footnotetext{
${ }^{31}$ Hedgers remove the need for precautionary saving, thereby increasing their propensity to consume. There is some, albeit limited, empirical evidence supporting this (McCarthy, 1995)
} 
are faced with the situation in which one country is relatively more reasonable for future investment or consumption flows. An alternative aspect of the exchange rate channel is that of interest rate parity, which transmits domestic policy abroad, and foreign policy home. It can be argued that the arrival of large-scale over-the-counter currency markets increases the strength of the covered interest rate parity relationship. Moreover, through the link from derivative markets to spot markets, it will ultimately strengthen the uncovered interest rate parity relationship (see in this respect Berk and Knot, 2001). The implication is an increased international interdependency of interest rates, and greater international capital flows following policy changes that change interest rates. Or, to put it differently, derivatives allow zero-risk arbitrage portfolios to be set up, forcing harmonisation of the relationship between exchange rates, foreign and domestic interest rates. Monetary policy inconsistent with domestic fundamentals or with foreign interest rates (or with the pegged exchange rate) will cause strong capital flows. Some of the counterparts of exchange rate derivative contracts, that is the agents who take over the risk from exporters or importers who want to insure themselves against exchange rate fluctuations, will be abroad. The total impact on domestic non-financial activity of a change in the exchange rate induced by a change in the cost of finance will therefore be reduced, but the reverse also holds. That is, foreign monetary policy can affect the domestic economy through foreign risk held domestically.

To the extent that the new economy, via globalisation of trade, leads to an increased openness of an economy to trade in goods and services, the exchange rate channel of monetary transmission will increase in importance. This exchange rate channel touches upon the broader aspect of the effect of the new economy on international interdependence of monetary transmission mechanisms. Rapid advances in ICT not only have brought many more investors into the international markets, but also have created a much greater degree of coherence in the attitudes and portfolio behaviour of investors who remain physically dispersed (Friedman, 1999). As financial globalisation advances, more and more central banks will find that attempts to control their short-term interest rates in a policy vacuum, that is, without regard for international economic developments, will not generate the desired domestic effects.

In sum, it is likely that in a new economic environment changes in the cost of finance will affect non-financial activity sooner, but the total impact will be less as more economic agents will be able to isolate themselves from these changes. Moreover, the mechanism of monetary transmission will be increasingly international (see in this respect also DeLong and Summers, 2001).

\section{The split between inflation and economic growth}

Our previous discussion showed that, because of real rigidities in the form of credit market imperfections, monetary policy can influence non-financial activity not (only) through interest rates but (also) through the availability of credit. In addition, the extent to which changes in non-financial activity generated by changes in the instrument variables translates into changes in prices and output, respectively, depends largely on the behaviour of wage and price setters. In general, the greater the 
degree of nominal wage and price flexibility, the more changes in non-financial activity affect prices and not output. Wage and price behaviour, in turn, is influenced by inflation expectations as well as by institutional factors. The introduction of the rational expectations hypothesis (Muth, 1961), to macroeconomics by Lucas (1972), Sargent (1976) and Sargent and Wallace (1975), led to expectational effects being explained in terms of concepts such as credibility and reputation of the policy maker. The institutional framework in which this interaction between the policy maker and the private sector takes place stresses factors which inhibit the continuous clearing of markets. Rational expectations are thus compatible with non-market clearing due to various (institutional) barriers to rapid adjustment of prices and wages (Fischer, 1977; Blinder, 1991; Ball and Mankiw, 1994). The most notable explanations as regards the causes of these rigidities include legal and institutional barriers to price adjustments (such as rent controls) and monopolistic or oligopolistic competition in product markets (Gordon, 1990; Mankiw and Romer, 1991). But also in a competitive environment, price inertia may result from the existence of menu costs in changing prices or from a desire by firms not to damage long-term relationships with clients by frequent variations in prices. As regards wage rigidities, explanations also focus on factors hindering competition, such as regulatory impediments to wage adjustments (e.g. minimum wages), the influence of unions and generous unemployment benefit schemes. ${ }^{32}$ On the other hand, even where competition is fierce but information is distributed asymmetrically, there may be a desire of both firms and workers to have longer-term working relationships entailing an implicit insurance against excessive wage volatility, or firms may refrain from downward wage adjustments in order not to jeopardise employee motivation and labour productivity. Moreover, from the hysteresis literature (Cross, 1988), wage rigidities causing unemployment persistence are explained with insider-outsider and duration theories of the wage bargaining process.

It follows that the behaviour of markets will be an important factor in determining how and with what speed a change in the cost of finance is spills over into economic growth (ie quantities) or inflation (prices), see in this respect also Cavelaars (2001). In discussing the effects of the new economy on the functioning of markets, we will mainly restrict ourselves to the availability and

access to information. ${ }^{33}$ In that respect, a useful distinction can be made between goods information and information goods, see Hirschleifer and Riley (1995). The former have no intrinsic value; they relate to information about products, and aim at (and derive their value from) improving the decisions

\footnotetext{
${ }^{32}$ For recent discussions of rigidities in the labour market, see Akerlof, Dickens and Perry (1996, 2000).

${ }^{33}$ Other factors that are likely to play a role in this respect, partly touched upon in previous sections, include financial market liberalisation and globalisation, and trade liberalisation, which can increase the degree of competition, productivity growth, and (by de-materialising output) reduce transportation costs. Moreover, more prudent fiscal policy has the potential to significantly reduce market distortions by containing crowding-out effects, and the succesful pursuit of price stability improves the working of the relative price mechanism, leading to more efficient resource allocation.
} 
made by economic agents. ${ }^{34}$ The conclusion that the more widespread use of ICT brings the economy more to the textbook model of perfect competition is mainly due to the likelihood of a more comprehensive and cheaper exchange of goods information, to such a extent that all the goods information ultimately becomes incorporated in the prices of goods. In general, the diffusion of ICT allows for a more efficient processing of information which (by reducing search costs) lowers transaction costs. Moreover, by further enhancing an integrated approach in which information systems of various participants within the supply chain are interlinked (so-called connectivity), productivity growth is increased, see for example Meijers (2000), Sijben (2000). ${ }^{35}$ This improves the functioning of markets in that agents are in a better position to find a solution to the 'signal processing problem' (Lucas, 1977). The latter relates to the issue of determining whether observed movements in prices reflect a shift in the general price level or in relative prices, and are permanent or transitory. ${ }^{36}$ The solution to this problem will determine whether economic agents change their spending decisions, which will in turn determine whether real variables will change. ${ }^{37}$ In an utopian new economy world with goods and goods information all information asymmetries will be eliminated, and the Walrasian auctioneer will determine equilibrium relative prices. ${ }^{38}$ In general, though, before this world becomes reality, fluctuations in the cost of finance will elicit relatively quicker price adjustments, with less effect on quantities. ${ }^{39}$

Information goods (goods that can be represented in digital form) on the other hand are an end in themselves, ie they directly enter into production or utility functions. Examples of information goods used in production include word processors and databases, whereas consumers derive utility from information goods mainly from their entertainment value. The production and distribution of information goods are characterised by the public good properties of non-rivalness and nonexcludability (Arrow, 1962). This implies that the advent of information goods in the economy is not a move towards the classical textbook model of perfect competition, in which an infinite number of small price-taking entities compete. Instead, competition in this world is more akin to the Schumpeterian concept. ${ }^{40}$ Increased returns to scale on the supply side on the market for information

\footnotetext{
${ }^{34}$ This of course does not imply that goods information cannot be traded in markets, as the real-life example of real estate agents shows.

${ }^{35}$ More and cheaper access to information also improves the functioning of the labour market, by making the matching process more efficient and reducing frictional unemployment.

${ }^{36}$ The ensuing improvement in the co-ordinating capabilities of modern decentralised market economies is illustrated by the more optimal use of inventories. This, in turn, may help to dampen busines cycle fluctuations, see McConnell et al. (2000)

${ }^{37}$ A purely transitory change in the relative price will not elicit a change in behaviour, and nor will a change in the general price level. See Lucas (1977) for a formal exposition.

${ }^{38}$ Supplemented by a fully frictionless financial world the general price level would be meaningless, as would be monetary policy. However, if society were to express a preference for a single unit of account, its value could be regulated by a central bank, and there will exist an equilibrium level of money prices (Woodford, 1998). See section 4.

${ }^{39}$ This will lead to permanent effects on equilibrium price and output levels, with transistory effects on economic growth and inflation. For similar arguments, see for example Herings and Schinkel (2000).

${ }^{40}$ Note the interaction of the various forces associated with the new economy. In particular, the deepening and development of financial markets discussed above tends to improve especially the growth prospects of young, dynamic
} 
goods tend to interact with network effects on the demand side to create powerful incentives for natural monopolies, see Varian (2001). This results in a market structure characterised by a small number of large price-setting entities. Profit maximisation by a traditional monopolist implies restricting supply and rising the price, leading to higher prices than in the conventional competitive paradigm. Monopolies in the market for information goods may however prove less harmful, as the pressure of technological change elicits a dynamism which will ensure that there exists a rivalry between alternating or succeeding monopolies, ie contestability is always possible (DeLong and Summers, 2001). ${ }^{41}$ The result will be that firms operating in the market for information goods will compete by lowering the price and increase output (Shapiro and Varian, 1999).

If the weight of information goods in a new economic environment is relatively small, chances are that the economy will move towards the traditional classical paradigm, with the concomitant behaviour of markets and the consequences for the passthrough of changes in the cost of finance to prices and quantities (that is prices adjust quickly, with limited effects on quantities). If, on the other hand, this new economy will be dominated by information goods, this will imply a change in relative prices as resources are re-allocated towards these information goods. The general price level should be less affected, and will continue to be determined by monetary factors, especially in the long run (Lucas, 1977). The macro-economic effect of the advent of the new economy in terms of functioning of markets is therefore not clear-cut. The same applies for its effect on inflation and growth (Buiter, 2000). Investigating the implications of phenomena often associated with the new economy, such as lower profit margins, a lower NAIRU, a higher trend productivity growth, on inflation and output, in the short as well as in the longer run, requires the specification of a model. The theoretical basis for such a model is available, even for an economy dominated by information goods (see, for example, Meijers, 2000). So, just as the new economy is, in fact, not new, its effects can and should be discussed using readily available, that is existing, economic theory.

\section{Concluding remarks}

The new economy is generally interpreted as a supply-side phenomenon, driven by technological advances and structural changes, which, partly via more flexible and efficient labour, product and capital markets and increased competition, over time lead to a higher level and growth rate of potential output. Regarding the financial system, the new economy might also be associated with a tendency towards disintermediation, securitisation, the emergence of new financial instruments and increased financial wealth.

We have discussed how monetary policy transmission would look like in this new economic environment. Our most general conclusion is that monetary policy will be possible. It seems unlikely

\footnotetext{
and innovative firms, that is the type of firms that contribute mostly to the waves of creative destruction.

${ }^{41}$ In addition, the durable character of information goods will act as a catalyst for competition, see Herings and Schinkel (2000). The key issue for competition policy in the new economy therefore is not market share, but the abuse
} 
that new economy-induced developments would ever severely limit the possibility of central banks steering the overnight rate. Of course, methods for exercising this influence will have to be adapted to the new economic environment, but that is nothing new for central banks. As long as there remains some residual demand for base money, and there is every reason to expect that this will be the case, these changes will not have significant consequences. Even in the unlikely event that there are perfect substitutes for base money, the central bank will still be able to steer interest rates. However, it will probably require government backing, in the form of regulation that changes the structure of the financial system, or to financially support the central bank. By steering its 'nucleus', the overnight rate, the central bank is still able to anchor the term structure, and this interest rate channel of monetary transmission will gain in importance in a new economy. The speed by which this anchoring occurs increases, as will the speed at which changes in the cost of finance will affect non-financial activity. The impact of the latter will, however, be less.

Although not directly addressed previously, we would also like to argue that there remains a need for monetary policy in a new economy. Stories about the 'death of inflation' (Browne and Fell, 1994) are not firmly based on economic arguments, see also Wadhwani (2000). Even in the unlikely case in which the new economy would closely resemble the perfect competition paradigm, this would mean a better functioning of the price mechanism, that is of relative prices. This suggests that monetary policy actions will elicit primarily reactions in prices, with relatively less effects on quantities. Movements in the general price level will still occur, and there will remain a need for an authority entrusted with maintaining the stability of this price level. Monetary policy as we currently understand will be meaningless only in a utopian, fully frictionless, world because the latter has no general price level. However, it seems likely that even in this world there would be a single unit of account, the value of which can be regulated by a central bank. Moreover, the central bank in such a world is the only institution that cares about nominal variables, and therefore necessary for tying down the price level, see Costa and de Grauwe (2001).

Our discussion points to a number of policy relevant questions that warrant future research. The first is to provide the qualitative analysis presented here with quantitative underpinnings, investigating the relative importance of the effects of the new economy on the various transmission channels. Secondly, having discussed how the new economy changes the way monetary policy affects the economy, the policy maker is confronted with the natural follow-up question, that is how to conduct monetary policy in a new economy. This touches on issues as the permanent or transitory character of accelerations in productivity or real output growth, and whether this is accompanied by a permanent or transitory decline in the inflation rate. Providing answers to these questions would require a rigorous modelling effort (see in this respect Buiter, 2000) and lies beyond the scope of this paper. However, our analysis suggests that caution is warranted in interpreting new economy effects on inflation rates and economic growth as permanent. The new economy will, in the end, imply a shift 
in and better signalling properties of relative prices. After completing this relative price adjustment, the equilibrium price level will probably be lower, but the persistence of the effects on the inflation rate are murky, at best. Confronted with the uncertainty that prevails surrounding these issues, another relevant question for policy makers would be whether to conduct policy in a gradual or more aggressive fashion, that is should the central bank follow a policy of interest rate smoothing or stepping?

In the end, the new economy is not new, and the same holds for the toolkit needed for analysing its implications, as well as for the questions that confront the monetary policy maker operating in a new economic environment. The 'old' central banks therefore seem to have lost nothing of their relevance.

\section{REFERENCES}

Akerlof, G. (1970), 'The market for lemons: qualitative uncertainty and the market mechanism', Quarterly Journal of Economics, 84, pp. 488-500.

Akerlof, G., Dickens, W. and Perry, G. (1996), 'The macroeconomics of low inflation', Brookings Papers on Economic Activity, 1, pp. 1-59.

Akerlof, G., Dickens, W. and Perry, G. (2000), 'Near-rational wage and price setting and the long-run Phillips curve', Brookings Papers on Economic Activity, 1, pp. 1-60.

Allen, F. and Santomero, A.M. (1998), 'The theory of financial intermediation', Journal of Banking and Finance, 21, pp. 1461-1485.

Allen, F. and Santomero, A.M. (2001), 'What do financial intermediaries do?', Journal of Banking and Finance, 25 , pp. 271-294.

Arrow, K.J. (1962), ‘The economic implications of learning by doing', Review of Economic Studies, 29, pp. 115173.

Baily, M.N. (2001), 'Macroeconomic implications of the new economy', in: Federal Reserve Bank of Kansas City, 'Economic policy for the information economy', Jackson Hole, Wyoming, pp. 201-269..

Ball, L. and Mankiw, N.G. (1994), 'A sticky price manifesto', NBER Working Paper no 4677, NBER, Cambridge (MA).

Baltensperger, E. and Milde, H. (1976), Predictability of reserve demand, information costs and portfolio behaviour of commercial banks', Journal of Finance, 31, pp. 835-843.

Bank of International Settlements (1990), ' Report of the committee on interbank netting schemes of the central banks of the group of ten countries', BIS, Basle.

Bank of International Settlements (1994), 'National differences in interest rate transmission', CB 393, BIS, Basle.

Bank of International Settlements (1996a), 'Implications for central banks of the development of electronic money', BIS, Basle.

Bank of International Settlements (1996b), 'Central bank survey of foreign exchange and derivatives market activity', BIS, Basle.

Bank of International Settlements (1998), 'Implications of structural change for the nature of systemic risk', BIS Basle

Bank of England (1990), 'The interest rate transmission mechanism in the United Kingdom and overseas', Quarterly Bulletin, 30, pp. 198-214.

Bank of England (1999), 'The transmission mechanism of monetary policy', Quarterly Bulletin, 39, pp. 161-170.

Bartelsman, E. and Hinloopen, J. (2000), 'De verzilvering van een groeibelofte', in: Soete, L. (ed), 'ICT en de Nieuwe Economie, Preadviezen van de Koninklijke Vereniging voor de Staathuishoudkunde, pp. 61-83.

Bengtsson, I. (2000a), 'Money, other payment technques, and the unit of contracts', mimeo, Department of Economics, Lund University.

Bengtsson, I. (2000b), 'Superseding the quantity theory of money-The contractual approach to nominal prices', mimeo, Department of Economics, Lund University.

Bennett, P. and Peristiani, S. (2001), 'Are US reserve requirements still binding', Federal Reserve Bank of New York Economic Policy Review, 8, pp. 53-69.

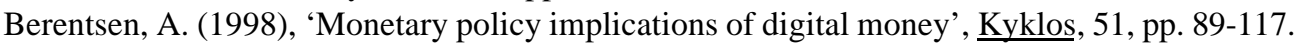

Berk, J.M. (2001), 'The Preparation of Monetary Policy', Boston: Kluwer Academic Publishers.

Berk, J.M. and Knot, K.H.W. (2001), 'Testing for long horizon UIP using PPP-based exchange rate expectations', 
Journal of Banking and Finance, 25, pp. 377-391.

Bernanke,B.S. (1983), 'Nonmonetary effects of the financial crisis in the propagation of the great depression', The American Economic Review, 73, pp. 257-276.

Bernanke, B.S. and Blinder, A.S. (1988), 'Credit, money, and aggregate demand', The American Economic Review, 78, pp. 435-439.

Bernanke, B.S. and Blinder, A.S. (1992), 'The Federal Funds Rate and the channels of monetary transmission', $\underline{\text { The }}$ American Economic Review, 82, pp. 901-921.

Bernanke, B.S. and Gertler, M. (1995), 'Inside the black box: The Credit Channel of monetary policy transmission', Journal of Economic Perspectives, 9, pp. 27-48.

Black, F. (1970), 'Banking and interest rates in a world without money', Journal of Bank Research, autumn, pp. 920.

Blinder, A. (1991), 'Why are prices sticky? Preliminary results from an interview study', The American Economic Review, 81, pp. 89-96.

Bodnar, G. and Marston, R. (1996), ‘1995 Survey of derivatives usage by US non-financial firms', George Weiss Center for International Financial Research, Wharton School, University of Pennsylvania.

Boeschoten, W.C. and Hebbink, G.E. (1996), 'Electronic money, currency demand and seigniorage loss in G-10 countries', DNB Staff Report, no 1, De Nederlandsche Bank, Amsterdam.

Bordo, M.D., Eichengreen, B. and Kim, J. (1998), 'Was there really an earlier period of international financial integration comparable to today?', NBER Working Paper, no 6738, NBER, Cambridge (MA).

Bordo, M.D., Eichengreen, B. and Irwin, D.A. (1999), 'Is globalisation today really different than (sic) globalisation a hundred years ago?', NBER Working Paper, no 7195, NBER, Cambridge (MA).

Bossone, B. (2001), 'Should banks be narrowed?', IMF Working Paper, WP/01/159, IMF, Washington.

Browne, F.X. and Cronin, D. (1997), 'Payment technologies, financial innovation, and laissez faire banking: a further discussion of the issues'. In: Dorn, J.A (ed), 'The Future of Money in the Information Age, The Cato Institute, Washington DC, pp. 153-165.

Browne, F.X and Fell, J.P.C. (1994), 'Inflation-dormant, dying or dead?', Technical Paper, 6/RT/94, Central Bank of Ireland

Buiter, W.H. (2000), 'The new economy and the old monetary economics', Bank of England Quarterly Bulletin, 40, pp. 173-183.

Bullard, J. and Schaling, E. (2000), 'New economy-New policy rules?', Working Paper no 2000-019A, Federal Reserve Bank of St Louis.

Capel, J. and Jansen, J. (2001), 'Vermogensprijsinflatie op de aandelenmarkt: analyse, gevolgen en beleidsimplicaties', Financial and Monetary Studies, forthcoming.

Cavelaars, P.A.D (2001), 'Monetary policy and competition policy in a two-country, two sector model', MEB series, 2001-02, De Nederlandsche Bank, Amsterdam.

Chami, R., Cosimano, T.F. and Fullenkamp, C. (1999), 'The stock market channel of monetary policy', IMF Working Paper, WP/99/22, International Monetary Fund, Washington DC.

Cecchetti, S.G. (2000), 'Early warning signs of the US productivity pickup: implications for Europe', mimeo.

Cooley, T.F. and Hansen, G.D. (1995), 'Money and the business cycle', in Cooley, T.F. (ed), Frontiers of Business Cycle Research, Princeton University Press, Princeton, pp. 175-216.

Costa, C. and De Grauwe, P. (2001), 'Monetary policy in a cashless society', CEPR Discussion Paper, no 2696.

Crockett , A.D. (1994), 'Rules versus discretion in monetary policy', in Beaufort Wijnholds, J.O. de, Eijffinger, S.C.W. and Hoogduin, L.H. (eds), 'A framework for monetary stability', Kluwer Academic Publishers, Dordrecht, pp. 165-185.

Cross, R. (ed), (1988), 'Unemployment, hysteresis, and the natural rate of unemployment', Basil Blackwell, Oxford.

Dale, S. and Haldane, A. (1993), 'Bank behaviour and the monetary transmission mechanism', Bank of England Quarterly Bulletin, 33, pp. 478-491.

Dalziel, P. (2000), 'On the evolution of money and its implications for price stability', Journal of Economic Surveys', 14, pp. 373-393.

D'Avolio, G., Gildor, E. and Shleifer, A. (2001), 'Technology, information production, and market efficiency', in: Federal Reserve Bank of Kansas City, 'Economic policy for the information economy', Jackson Hole, Wyoming, pp. 125-161.

DeLong, J.B. and Summers, L.H. (2001), 'The 'New Economy': Background, questions and speculations', in: Federal Reserve Bank of Kansas City, 'Economic policy for the information economy', Jackson Hole, Wyoming, pp. 11-47.

Edwards, F. and Mishkin, F.S. (1995), 'The decline of traditional banking: implications for stability and regulatory policy', Federal Reserve Bank of New York Review, 1, pp. 27-45.

Ely, B. (1997), Electronic money and monetary policy: separating facts from fiction' In: Dorn, J.A (ed), 'The Future of Money in the Information Age, The Cato Institute, Washington DC, pp. 101-115.

England, C. (1997), 'The future of currency competition', In: Dorn, J.A (ed), 'The Future of Money in the 
Information Age, The Cato Institute, Washington DC, pp. 137-153.

Estrella, A. (2001), 'Securitization and the efficacy of monetary policy', Federal Reserve Bank of New York Economic Policy Review, 8, pp. 243-257.

European Central Bank (2000a), 'Potential output growth and output gaps: concept, uses and estimates', Monthly Bulletin, October, pp. 37-49.

European Central Bank (2000b), 'Issues arising from the emergence of electronic money', Monthly Bulletin November, pp. 49-60.

European Union (2000), 'The contribution of information and communication technologies to growth in Europe and the US: a macroeconomic analysis', European Economy, Supplement A, no 12.

Fama, E. (1980), 'Banking in the theory of finance', Journal of Monetary Economics, 6, pp. 39-57.

Fama, E. (1983), 'Financial intermediation and price level control', Journal of Monetary Economics, 12, pp. 7-28.

Fender, I. (2000a), 'Corporate hedging: the impact of financial derivatives on the broad credit channel of monetary policy’, BIS Working Paper, 94, BIS, Basle.

Fender, I. (2000b), 'The impact of corporate risk management on monetary policy transmission: some empirical evidence', BIS Working Paper, 95, BIS, Basle.

Fischer, S. (1977), 'Long-term contracts, rational expectations, and the optimal money supply rule', Journal of Political Economy, 85, pp. 191-206.

Freedman, C. (2000), 'Monetary policy implementation: past, present, future: will the advent of electronic money lead to the demise of central banking?', International Finance, pp. 211-227.

Friedman, B.M. (1999), 'The future of monetary policy: the central bank as an army with only a signal corps?, International Finance, 2, pp. 321-338.

Friedman, B.M. (2000a), 'Decoupling at the margin: the threat to monetary policy from the electronic revolution in banking', International Finance, 3, pp. 261-272.

Friedman, B.M. (2000b), 'The threat to monetary policy from the electronic revolution in banking', Paper prepared for the Cato Institute 18th Annual Monetary Conference Monetary Policy in the New Economy, October 2000, Washington DC.

Gilbert, R.A. (1997), 'Financial regulation in the information age', In: Dorn, J.A (ed), 'The Future of Money in the Information Age, The Cato Institute, Washington DC, pp. 71-81.

Goodhart, C.A.E. (1986), 'Why do we need a central bank?', Discussion paper no 57, Banca d'Italia.

Goodhart, C.A.E. (1988), 'The Evolution of Central Banks', The MIT Press, Cambridge (MA)

Goodhart, C.A.E. (1989), 'Money, Information and Uncertainty', Macmillan, London.

Goodhart, C.A.E. (1993), 'Can we improve the structure of financial systems?', European Economic Review, 37, pp. 269-291.

Goodhart, C.A.E. (2000), 'Can central banking survive the IT revolution?', International Finance, 3, pp.189-209.

Gordon,R.J. (1990), 'What is New-Keynesian economics?', Journal of Economic Literature, 27, pp. 1115-1171.

Gordon, R.J. (2000), 'Does the 'new economy' measure up to the great inventions of the past?, Journal of Economic Perspectives, 14, pp. 49-75.

Greenspan, A. (1997), 'Fostering financial innovation: the role of government', In: Dorn, J.A (ed), 'The Future of Money in the Information Age, The Cato Institute, Washington DC, pp. 45-51.

Groeneveld, J.M. and Visser, A. (1997), 'Seigniorage, electronic money and financial independence of central banks', Banca Nazionale del Lavoro Quarterly Review, 200, pp. 69-88.

Hall, R.E. (1999), 'Controlling the price level', NBER Working Paper, no 6914, NBER, Cambridge (MA).

Hayek, F.A. (1976), 'The denationalization of money:an analysis of the theory and practice of concurrent currencies', Reprinted in: Kresge, S. (1999), ‘The Collected Works of F.A. Hayek, vol VI, Routledge, London.

Hayek, F.A. (1978), 'Choice in currency: a way to stop inflation'. Reprinted in: Kresge, S. (1999), 'The Collected Works of F.A. Hayek, vol VI, Routledge, London.

Heerings, P. J.J. and Schinkel, M.P. (2000), 'World-Wide-Welfare: een micro-economische analyse van de nieuwe economie', in: Soete, L. (ed), 'ICT en de Nieuwe Economie, Preadviezen van de Koninklijke Vereniging voor de Staathuishoudkunde, pp. 137-177.

Henckel, T., Ize, A. and Kovanen, A. (1999), 'Central banking without central bank money', IMF Working Paper, WP/99/92, IMF, Washington.

Hessius, K. (2000), 'The new economy seen from a central bank perspective', lecture delivered in Stockholm, 12 October 2000.

Hirschleifer, J. and Riley, J.G. (1995), 'The analytics of uncertainty and information', Cambridge University Press, Cambridge

Houben, A. and Kakes, J. (2001), 'Fostering the new economy: the role of financial intermediation', MEB Series no 2001-07, Monetary and economic policy department, De Nederlandsche Bank, Amsterdam.

Hubbard, R.G. (1994), 'Is there a credit channel for monetary policy?', NBER Working Paper no 4977, Cambridge (MA).

Issing, O. (1999), ' Hayek-currency competition and European Monetary Union', Annual Hayek Memorial Lecture 
delivered at The Institute of Economic Affairs, 27 May 1999.

Issing, O. (2000), 'New technologies in payments-a challenge to monetary policy', Lecture delivered at the centre for financial studies, Frankfurt am Main, 28 June 2000.

Jordan, J.L. and Stevens, E.J. (1997), 'Money in the 21 st century', In: Dorn, J.A (ed), 'The Future of Money in the Information Age, The Cato Institute, Washington DC, pp. 115-127.

Jorgenson, D.W. and Stiroh, K.J. (2000), 'Raising the speed limit: US economic growth in the information age', Brookings Papers on Economic Activity, 1, pp. 125-235.

Kabelac, G. (1999), 'Cyber money as a medium of exchange', Discussion Paper, 5/99, Economic Research Group, Deutsche Bundesbank, Frankfurt.

Kahn, H. and Wiener, A.J. (1967), 'The year 2000: A framework for speculation on the next 33 years', Macmillan, London

Kashyap, A.K. and Stein, J.C. (1994), 'Monetary policy and bank lending', in Mankiw, N.G. (ed), 'Monetary Policy', University of Chicago Press, Chicago, pp. 221-256.

Kashyap, A.K., Stein, J.C. and Wilcox, D.W. (1993), 'Monetary Policy and credit conditions: evidence from the composition of external finance', The American Economic Review, 83, pp. 78-99.

King, M. (1999), 'Challenges for monetary policy: new and old' In: Federal Reserve Bank of Kansas City, New Challenges for Monetary Policy, pp. 11-59.

Kydland, F. and Prescott, E. (1982), 'Time to build and aggregate fluctuations', Econometrica, 50, pp. 1345-1370.

Lahdenperä, H. (2001), 'Payment and financial innovation, reserve demand and implementation of monetary policy', Bank of Finland Discussion Papers, 26-2001.

Lelieveldt, S.L., Groeneveld, J.M., Katee, S.G.A and Visser, A. (2000), 'Electronisch betalen:afrekenen met een verleden', Financial and Monetary Studies, 18, no 2.

Lucas, R.E. (1972), 'Expectations and the neutrality of money', Journal of Economic Theory, 4, pp. 103-124.

Lucas, R.E. (1977), 'Understanding business cycles', reprinted in Lucas, R.E. (1985), 'Studies in business cycle theory', The MIT Press, Cambridge (MA), pp. 215-240.

Mankiw, N.G. and Romer, D. (1991), 'New Keynesian Economics', The MIT Press, Cambridge (MA).

Mauskopf, E. (1990), 'The transmission channels of monetary policy: how have they changed?', Federal Reserve Bulletin, 76, pp. 985-1008.

McCallum, B.T. (2000), 'The present and future of monetary policy rules', mimeo, Carnegie-Mellon University.

McCarthy, J. (1995), 'Imperfect insurance and differing propensities to consume across households', Journal of Monetary Economics, 36, 2, pp. 301-327

McConnell, M.M., Mosser, P.C. and Peres Quiros, G. (1999), 'A decomposition of the increased stability of GDP growth', Current Issues, Federal Reserve Bank of New York, 5, pp1-6.

McTeer, B. (2000), 'Monetary policy in the new economy', Paper prepared for the Cato Institute 18th Annual Monetary Conference Monetary Policy in the New Economy, October 2000, Washington DC.

Meltzer, A.H. (1995), 'Monetary, credit and (other) transmission processes: a monetarist perspective', Journal of Economic Perspectives, 9, pp. 49-73.

Meltzer, A.H. (2001), 'The transmission process'. In: Deutsche Bundesbank (ed), 'The monetary transmission process: recent developments and lessons for Europe, Palgrave, New York.

Menon, J. (1995), 'Exchange rate passthrough', Journal of Economic Surveys, 9, pp. 197-231.

Meyers, H. (2000), 'Internethandel en lage inflatie in de informatie-economie', in: Soete, L. (ed), 'ICT en de Nieuwe Economie, Preadviezen van de Koninklijke Vereniging voor de Staathuishoudkunde, pp. 83-105.

Mishkin, F.S. (1995), 'Symposium on the monetary transmission mechanism', Journal of Economic Perspectives, 9, pp. 3-10.

Mishkin, F.S. (1996), 'The channels of transmission: lessons for monetary policy', NBER Working Paper no 5464, NBER, Cambridge (MA).

Modigliani, F. (1971), 'Monetary policy and consumption'. In Federal Reserve Bank of Boston, 'Consumer Spending and Monetary Policy: The Linkages, June 1971.

Modigliani, F. and Miller, M.H. (1958), 'The cost of capital, corporation finance and the theory of investment', The American Economic Review, 48, pp. 261-297.

Modigliani, F. and Shiller, R. (1973), 'Inflation, rational expectations and the term structure of interest rates', Economica, 40, pp. 12-43.

Mojon, B. (2000), 'Financial structure and the interest rate channel of ECB monetary policy', European Central Bank Working Paper Series, 40.

Muth, J.F. (1961), 'Rational expectations and the theory of price movements', reprinted in Lucas, R.E. and Sargent, T.J. (eds), 'Rational expectations and econometric practice', George Allen and Unwin, London, pp. 3-23.

OECD (2000), 'A new economy? The changing role of innovation and information technology in growth', OECD, Paris.

Oliner, S.D. and Rudebusch, G.D. (1996), 'Is there a broad credit channel for monetary policy?', Federal Reserve Bank of San Fransisco Economic Review, 1, pp. 3-13. 
Oliner, S.D. and Sichel, D.E. (2000), 'The resurgence of growth in the late 1990's: Is information technology the story?, Journal of Economic Perspectives, 14, pp. 3-23.

Plosser, C.I. (2000) 'Does the 'New Economy' call for a 'New' monetary policy?' Paper prepared for the Cato Institute 18th Annual Monetary Conference Monetary Policy in the New Economy, October 2000, Washington DC.

Poole, W. (1968), 'Commercial bank reserve management in a stochastic model: implications for monetary policy', Journal of Finance, 23, pp. 769-791.

Rahn, R.W. (2000), 'The impact of digital money on central banks', Paper prepared for the Cato Institute18th Annual Monetary Conference Monetary Policy in the New Economy, October 2000, Washington DC.

Sargent, T.J. and Wallace, N. (1975), 'Rational expectations, the optimal monetary instrument, and the optimal money supply rule', reprinted in Lucas, R.E. and Sargent, T.J. (eds), 'Rational expectations and econometric practice', George Allen and Unwin, London, pp. 215-229.

Sargent, T.J. (1976), 'A classical macroeconometric model for the United States', reprinted in Lucas, R.E. and Sargent, T.J. (eds), 'Rational expectations and econometric practice', George Allen and Unwin, London, pp. 521-553.

Shapiro, C. and Varian, H.C. (1999), 'Information Rules-A Strategic Guide to the Network Economy', Harvard Business School Press, Boston (MA)

Sellon, G.H. and Weiner, S.E. (1996), 'Monetary policy without reserve requirements: analytical issues', Federal Reserve Bank of Kansas City Economic Review, 1996-IV, pp. 5-24.

Sellon, G.H. and Weiner, S.E. (1997), 'Monetary policy without reserve requirements: case studies and options for the United States', Federal Reserve Bank of Kansas City Economic Review, 1997-II, pp. 5-30.

Shiller, R.J. (1993), 'Macro Markets: creating institutions for managing society's largest economic risks', The Clarendon Press, Oxford.

Sijben, J.J. (2000), 'De 'nieuwe economie' en de monetaire politiek', mimeo.

Stiglitz, J.E. and Weiss, A. (1981), 'Credit rationing in markets with imperfect information', The American Economic Review, 71, pp. 393-410.

Taylor, J.B. (1995), 'The monetary transmission mechanism: an empirical framework', Journal of Economic Perspectives, 9, pp. 11-27.

Thornton, D.L. (1994), 'Financial innovation, deregulation and the credit view of monetary policy', Federal Reserve Bank of St Louis Review, January/february, pp. 31-49.

Tobin, J. and Brainard, W.C. (1963), 'Financial intermediaries and the effectiveness of monetary controls'; American Economic Review, 53, pp. 383-400.

Varian, H.R. (2001), 'High-technology industries and market structure, in: Federal Reserve Bank of Kansas City, 'Economic policy for the information economy', Jackson Hole, Wyoming, pp. 65-103.

Visser, A. (1996), 'Electronisch geld, monetair beleid en de winst van DNB', Economisch-Statistische Berichten, 81, pp. 684-688.

Vrolijk, C. (1997), 'Derivatives effect on monetary policy transmission', IMF Working Paper, WP/97/121, IMF, Washington.

Wadhwani, S. (2000), 'Monetary challenges in a 'New Economy', Bank of England Quarterly Bulletin, 40, pp. 411-422.

Wadhwani, S. (2001), 'The new economy: myths and realities', Bank of England Quarterly Bulletin, 41, pp. 247.

White, L.H. (1984), 'Competitive payments systems and the unit of account', American Economic Review, 74, pp. 699-712.

White, L.H. (1989), ‘Competition and currency', New York University Press, New York.

White, L.H. (1997), ‘The technology revolution and monetary evolution', In: Dorn, J.A (ed), 'The Future of Money in the Information Age, The Cato Institute, Washington DC, pp. 15-20.

White, L.H. (2000), 'In what respects will the information age make central banks obsolete?', Paper prepared for the Cato Institute 18th Annual Monetary Conference Monetary Policy in the New Economy, October 2000, Washington DC.

Woodford, M. (1998), 'Doing without money: controlling inflation in a post-monetary world', $\underline{\text { Review of Economic }}$ Dynamics, 1, pp. 173-219.

Woodford, M. (2000), 'Monetary policy in a world without money', International Finance, 3, pp.229-260.

Woodford, M. (2001), 'Monetary policy in the information economy', in: Federal Reserve Bank of Kansas City, 'Economic policy for the information economy', Jackson Hole, Wyoming, p 297-371. 